Journal of Educational Technology

\& Online Learning

Volume 2 | Issue 3 | 2019

http://dergipark.gov.tr/jetol

\title{
Book Review: Managing and Designing Online Courses in Ubiquitous Learning Environments
}

\section{Şeyda KIR ${ }^{\mathrm{a}}$}

a seydaakr@gmail.com; Anadolu University, Eskişehir, Turkey; ORCID: 0000-0002-6270-8034

Doi: 10.31681 /jetol.622842

Suggested citation: Kır, Ş. (2019). Book Review: Managing and Designing Online Courses in Ubiquitous Learning Environments. Journal of Educational Technology \& Online Learning, 2(3), 136-142.

\begin{tabular}{|c|c|}
\hline Article Info & Abstract \\
\hline Received: 20.09 .2019 & The work "Managing and Designing Online Courses in Ubiquitous Learning \\
\hline Accepted: 30.09 .2019 & Environments" authored by Gürhan Durak (Balıkesir University, Turkey) and Serkan \\
\hline & $\begin{array}{l}\text { in 2020. The meta data of the book is as followings: ISBN13: } 9781522597797 \text {; ISBN10: } \\
\text { 1522597794; EISBN13: } 9781522597810 \text {; DOI: } 10.4018 / 978-1-5225-9779-7 \text {. }\end{array}$ \\
\hline
\end{tabular}

Book Review

Keywords: Ubiquitous Learning, Seamless Learning, Online Learning, Distance Education, Open and Distance Learning

\section{INTRODUCTION}

Premier Reference Source

Managing and Designing

Online Courses in Ubiquitous

Learning Environments

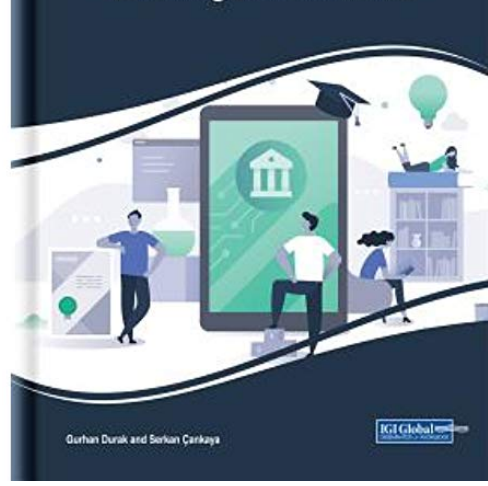

The work "Managing and Designing Online Courses in Ubiquitous Learning Environments" authored by Gürhan Durak (Balıkesir University, Turkey) and Serkan Çankaya (İzmir Democracy University, Turkey). The book was published by IGI Global in 2020. The meta data of the book is as followings: ISBN13: 9781522597797; ISBN10: 1522597794; EISBN13: 9781522597810; DOI: 10.4018/978-1-5225-9779-7.

\section{LITERATURE}

This book named 'Managing and Designing Online Course in Ubiquitous Learning Environments' consists of 13 chapters. Each chapter of the book provides essential empirical and theoretical research perspectives on online learning environments and ubiquitous learning 
technologies. The main topics that the authors focused on are ubiquitous learning, distance learning, e-learning, technology integration, online learning environments, learning management systems, educational resources, heutagogy, MOOC (Massive Open Online Courses), and online career counseling etc.

Chapter 1: "Online Learning Support in a Ubiquitous Learning Environment" authored by Mphahlele (2020) identifies ubiquitous learning environment (ULE) using technology for curriculum delivery as core subject for online learning support. This chapter also focuses on the challenging relationship between online learning support and ULE considering that online learning support is not assumed as a significant pedagogical resource for ubiquitous learning environments.

Chapter 2: "A Specified Ubiquitous Learning Design for Seamless Learning” authored by Deryal and Demirer (2020) differentiates the concepts of seamless learning, ubiquitous computing and ubiquitous learning with a great extent of scope. After these concepts explication the author proposes an efficient seamless learning management system.

Chapter 3: "Supporting Digital Information Literacy in the Age of Open Access: Considerations for Online Course Design" authored by Felber and Roubides (2020) introduces the issue of open access sources which is associated with accessing to educational resources and incorporating digital information literacy into whole educational settings.

Chapter 4: "Learning Communities: Theory and Practice of Leveraging Social Media for Learning" authored by Robinson, Kilgore and Bozkurt (2020) explains the changing characteristics of online learning environments and further explores similarities and differences of three learning communities: communities of practice (CoPs), professional learning communities (PLCs), and professional learning networks (PLNs).

Chapter 5: "Enhancing Personal Professional Development Through Technology Integration: The Need for Ubiquitous Learning” authored by İzmirli and Çalışkan (2020) defines the professional development as a whole process depending on the needs of adults. This chapter studies personal professional development trainings in the context of ubiquitous learning environments and discusses the factors affecting professional development activities and how the needs of adults can be integrated into professional development trainings within the context of technology integration. 
Chapter 6: "Seamless Learning Design Criteria in the Context of Open and Distance Learning" authored by Yetik, Ozdamar and Bozkurt (2020) provides the criteria for the design of seamless learning environments in the context of ODL.

Chapter 7: "Supporting Learners with Special Needs in Open and Distance Learning" authored by Genc and Kocdar (2020) examines the support services of the learners with special needs in Open and Distance Learning (ODL) environments. The authors also focus on the accommodations for learners with special needs in ODL institutions and the cruciality of accomodations of learners with special needs while designing an online course in a ubiquitous learning environment.

Chapter 8: "The Contribution of Information Communication Technologies in Online Career Counseling: Case Study of an Online Community Within Higher Education" authored by Mouratoglou and Zarifis (2020) explores the process of designing an online career counseling for higher education students and graduates. The authors also point out the factors affecting participants' learning experiences throughout the online career counseling.

Chapter 9: "Ubiquitous Learning for New Generation Learners' Expectations" authored by Kişla and Karaoğlan (2020) highlights the characteristics of generations which is defined as a group of people who have similar life experiences in the same timeframe. Within this context, this chapter identifies the ubiquitous learning approach taking full account of the expectations of new generation learners.

Chapter 10: "Considering Social Presence in the Designing of Ubiquitous Learning Environments" authored by İzmirli (2020) describes ubiquitous learning and social presence and explains how to apply elements of social presence in designing a ubiquitous learning environment. Furthermore, the author exemplifies the implementation of ubiquitous learning environment by providing the sample of ubiquitous history museum.

Chapter 11: "From Ubiquitous to Ubiquitous Blended Learning Environments" authored by Ateş-Çobanoğlu (2019) classifies blended learning and ubiquitous blended learning which are becoming even more valuable through the process of designing online courses. The author presents some ideas in which aspects ubiquitous learning environments have gained attention in order to design online courses and suggests a rationale about how to use such online designs.

Chapter 12: "The Challenges and Opportunities of Partnership in Establishing Online Postgraduate Provision" authored by Taylor (2020) point out an objective perspective on getting into a partnership with a higher education service provider while developing an online learning environment. 
Chapter 13: “A Framework for Developing Open Distance E-Learning Curriculum for Library and Information Science (LIS) Programme in Eswatini" authored by Tsabedze (2020) offers a framework for the learners of LIS programme thanks to the opportunities which are provided from the flexibility of open distance e-learning curriculum.

Chapter 14: "The Usability of Mobile Devices in Distance Learning" authored by Sarsar, Kişla, Karasu, Arıkan and Kılıç (2020) investigates the progress of interaction between the instructors and learners by using mobile devices in the context of distance learning environment. The authors probe how instructors' interaction techniques have an impact on the quality of teaching and learning processes and experiences also.

Chapter 15: "Ubiquitous Learning and Heutagogy in Teacher Education" authored by Ceylan (2020) identifies ubiquitous learning and heutagogical approach which is defined as a flexible and non-linear learning process that the learners take the responsibility of their own learning experience. The chapter presents how ubiquitous learning and heutagogical approach can be implemented in teacher education and offers a heutagogical ubiquitous learning interaction for teacher education and the professional development in consideration of technology and digital environments needed for ubiquitous learning environment.

Chapter 16: "Transition From E-Learning to U-Learning: Basic Characteristics, Media, and Researches" authored by Parlakkılıç (2020) illustrate the features of ubiquitous learning which is a system depending on Ubiquitous Computing Technology. This chapter clarifies the transition process of how u-learning is in place of e-learning by taking the advantage of $\mathrm{u}$ learning ensuring learning service in any form, time and place.

\section{CONCLUSION}

With the rapid adaptation of technology and digital systems in educational settings, e-learning, $\mathrm{m}$-learning and u-learning have great potential on distance education and open and distance learning environments. Increasingly going on learners' needs and demand for flexible and personalized online learning programs supports the using of ubiquitous learning technologies in online learning environments. In this regard, Managing and Designing Online Courses in Ubiquitous Learning Environments (Durak \& Çankaya, 2020) is a reliable reference for curriculum developers, administrators, educators, higher education staff, practitioners, academicians, instructional designers, policymakers, and researchers. 


\section{About the Author}

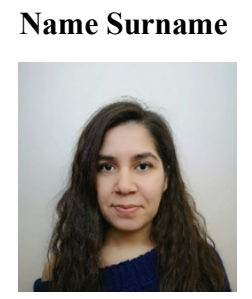

Sheyda Kır, is a PhD student in the Department of Distance Education at Anadolu University. She received her BA in English Language Teaching and MS in Distance Education Department at Anadolu University. She is interested in lifelong learning, adult education, MOOCs, open and distance learning and skills learning in distance learning environment and she is going on her researches on these fields.

Mailing Address: Anadolu University, Distance Educatioon Department, Eskişehir, Turkey

E-mail: seydaakr@gmail.com

\section{References}

Ateş-Çobanoğlu, A. (2020). From Ubiquitous to Ubiquitous Blended Learning Environments. In G. Durak, \& S. Çankaya (Eds.), Managing and Designing Online Courses in Ubiquitous Learning Environments (pp. 215-232). Hershey, PA: IGI Global. doi:10.4018/978-1-5225-9779-7.ch011

Ceylan, B. (2020). Ubiquitous Learning and Heutagogy in Teacher Education. In G. Durak, \& S. Çankaya (Eds.), Managing and Designing Online Courses in Ubiquitous Learning Environments (pp. 279-295). Hershey, PA: IGI Global. doi:10.4018/978-1-5225-97797.ch015

Deryal, I. E., \& Demirer, V. (2020). A Specified Ubiquitous Learning Design for Seamless Learning. In G. Durak, \& S. Çankaya (Eds.), Managing and Designing Online Courses in Ubiquitous Learning Environments (pp. 19-51). Hershey, PA: IGI Global. doi:10.4018/978-1-5225-9779-7.ch002

Felber, S., \& Roubides, P. (2020). Supporting Digital Information Literacy in the Age of Open Access: Considerations for Online Course Design. In G. Durak, \& S. Çankaya (Eds.), Managing and Designing Online Courses in Ubiquitous Learning Environments (pp. 52-71). Hershey, PA: IGI Global. doi:10.4018/978-1-5225-97797.ch003

Genc, H., \& Kocdar, S. (2020). Supporting Learners with Special Needs in Open and Distance Learning. In G. Durak, \& S. Çankaya (Eds.), Managing and Designing Online Courses in Ubiquitous Learning Environments (pp. 128-151). Hershey, PA: IGI Global. doi:10.4018/978-1-5225-9779-7.ch007

İzmirli, S. (2020). Considering Social Presence in the Designing of Ubiquitous Learning Environments. In G. Durak, \& S. Çankaya (Eds.), Managing and Designing Online 
Courses in Ubiquitous Learning Environments (pp. 201-214). Hershey, PA: IGI Global. doi:10.4018/978-1-5225-9779-7.ch010

İzmirli, Ö. Ş., \& Çalışkan, G. (2020). Enhancing Personal Professional Development Through Technology Integration: The Need for Ubiquitous Learning. In G. Durak, \& S. Çankaya (Eds.), Managing and Designing Online Courses in Ubiquitous Learning Environments (pp. 92-105). Hershey, PA: IGI Global. doi:10.4018/978-1-5225-97797.ch005

Kişla, T., \& Karaoğlan, B. (2020). Ubiquitous Learning for New Generation Learners' Expectations. In G. Durak, \& S. Çankaya (Eds.), Managing and Designing Online Courses in Ubiquitous Learning Environments (pp. 176-200). Hershey, PA: IGI Global. doi:10.4018/978-1-5225-9779-7.ch009

Mouratoglou, N., \& Zarifis, G. K. (2020). The Contribution of Information Communication Technologies in Online Career Counseling: Case Study of an Online Community Within Higher Education. In G. Durak, \& S. Çankaya (Eds.), Managing and Designing Online Courses in Ubiquitous Learning Environments (pp. 152-175). Hershey, PA: IGI Global. doi:10.4018/978-1-5225-9779-7.ch008

Mphahlele, R. S. (2020). Online Learning Support in a Ubiquitous Learning Environment. In G. Durak, \& S. Çankaya (Eds.), Managing and Designing Online Courses in Ubiquitous Learning Environments (pp. 1-18). Hershey, PA: IGI Global. doi:10.4018/978-1-52259779-7.ch001

Parlakkılıç, A. (2020). Transition From E-Learning to U-Learning: Basic Characteristics, Media, and Researches. In G. Durak, \& S. Çankaya (Eds.), Managing and Designing Online Courses in Ubiquitous Learning Environments (pp. 296-310). Hershey, PA: IGI Global. doi:10.4018/978-1-5225-9779-7.ch016

Robinson, H., Kilgore, W., \& Bozkurt, A. (2020). Learning Communities: Theory and Practice of Leveraging Social Media for Learning. In G. Durak, \& S. Çankaya (Eds.), Managing and Designing Online Courses in Ubiquitous Learning Environments (pp. 72-91). Hershey, PA: IGI Global. doi:10.4018/978-1-5225-9779-7.ch004

Sarsar, F., Kişla, T., Karasu, M., Arıkan, Y. D., \& Kılıç, M. (2020). The Usability of Mobile Devices in Distance Learning. In G. Durak, \& S. Çankaya (Eds.), Managing and Designing Online Courses in Ubiquitous Learning Environments (pp. 262-278). Hershey, PA: IGI Global. doi:10.4018/978-1-5225-9779-7.ch014 
Taylor, F. (2020). The Challenges and Opportunities of Partnership in Establishing Online Postgraduate Provision. In G. Durak, \& S. Çankaya (Eds.), Managing and Designing Online Courses in Ubiquitous Learning Environments (pp. 233-243). Hershey, PA: IGI Global. doi:10.4018/978-1-5225-9779-7.ch012

Tsabedze, V. W. (2020). A Framework for Developing Open Distance E-Learning Curriculum for Library and Information Science (LIS) Programme in Eswatini. In G. Durak, \& S. Çankaya (Eds.), Managing and Designing Online Courses in Ubiquitous Learning Environments (pp. 244-261). Hershey, PA: IGI Global. doi:10.4018/978-1-5225-97797.ch013

Yetik, E., Ozdamar, N., \& Bozkurt, A. (2020). Seamless Learning Design Criteria in the Context of Open and Distance Learning. In G. Durak, \& S. Çankaya (Eds.), Managing and Designing Online Courses in Ubiquitous Learning Environments (pp. 106-127). Hershey, PA: IGI Global. doi:10.4018/978-1-5225-9779-7.ch006 